\title{
ВMJ Global Health Market-driven, value-based, advance commitment (MVAC): accelerating the development of a pathbreaking universal drug regimen to end $\mathrm{TB}$
}

\author{
Kalipso Chalkidou, ${ }^{1,2}$ Adrian Towse, ${ }^{3}$ Rachel Silverman, ${ }^{1}$ Martina Garau, ${ }^{3}$ \\ Ganesh Ramakrishnan ${ }^{1}$
}

To cite: Chalkidou K, Towse A, Silverman R, et al. Market-driven, value-based advance commitment (MVAC): accelerating the development of a pathbreaking universal drug regimen to end TB. BMJ Global Health 2020;5:e002061. doi:10.1136/ bmjgh-2019-002061

Handling editor Seye Abimbola This paper is based on our full MVAC blueprint, published here.

Received 18 0ctober 2019 Revised 26 February 2020 Accepted 28 February 2020

\section{Check for updates}

(c) Author(s) (or their employer(s)) 2020. Re-use permitted under CC BY. Published by BMJ.

${ }^{1}$ Center of Global Development, Washington, District of Columbia, USA

${ }^{2}$ Global Health and Development Group, Imperial College London, London, United Kingdom ${ }^{3}$ Office of Health Economics, London, UK

Correspondence to Professor Kalipso Chalkidou; kchalkidou@cgdev.org

\section{CHRONIC UNDERINVESTMENT IN R\&D THREATENS THE TUBERCULOSIS RESPONSE}

Tuberculosis (TB), an infectious disease primarily affecting poor and neglected populations, kills an estimated 1.6 million men, women and children each year). ${ }^{1}$ Our existing arsenal of tools is insufficient to address this enormous burden. Current treatment cycles are long and toxic, causing some patients to discontinue treatment, acquire drug resistance and spread a drug-resistant pathogen to others. Treating drug-resistant cases takes even longer, is more expensive and less effective. More extensive forms of drug resistance are developing and spreading quickly. On the current trajectory, the world will not achieve the Convergence 2035 targets for TB until 2074, almost 40 years later than originally projected (see figure 1).

New diagnostics, drugs and vaccines, alongside stronger healthcare systems, are badly needed. All require investment-an estimated \$2 billion per year to drive the requisite technological innovation. ${ }^{2}$ Estimates for current researchand development (R\&D) investments reveal a large funding gap, with total investments of between just $\$ 615$ million $^{3}$ and $\$ 906$ million $^{4}$ per year (in 2018), and overwhelmingly donor financed. More than two-thirds were provided by the public sector ( $\$ 617$ million), with the US government financing around $60 \%$ of this (\$371 million). The remaining public sources are split between the UK (the second largest contributor), the European Union, India, Germany, Canada and South Korea. Private industry accounts for only $9 \%$ of total TB R\&D funding ( $\$ 85$ million in 2018)-accounting for less than $0.05 \%$ of total private-sector pharmaceutical R\&D investment and declining. ${ }^{5}$

\section{Summary box}

Tuberculosis (TB) is the world's deadliest infectious disease; without a significant technological breakthrough, current trajectories suggest that the world will not achieve the Convergence 2035 targets for TB until 2074, almost 40 years later than originally projected.

- Research and development investments for TB are dominated by public sources and total only one-third of estimated need, with private investment small and declining.

- To crowd in private investment, we suggest a new model-the market-driven,value-based advance commitment (MVAC) — wherein high-burden middleincome countries (MICs) would offer advanced purchase commitments for a prespecified breakthrough treatment regimen.

- Through use of early health technology assessment, an emerging practice and capability in many large MICs, the MVAC would ensure that country purchase commitments reflect local needs, value and ability to pay for innovation.

- A multilateral development bank would underwrite the MVAC commitments, increasing their credibility to private industry without requiring countries to put aside funds in advance.

- Discussion with developing country policymakers, industry, development banks and development partners suggest fertile ground for the MVAC approach, but high-level political commitment is still needed.

Philanthropic funding totalled \$159 million in 2018, with almost $90 \%$ provided by the Gates Foundation. Finally, 5\% of total TB $\mathrm{R} \& D$ in 2018 was given by multilateral funding, mainly financed by Unitaid. ${ }^{4}$

The resulting funding shortfall (over $\$ 1$ billion) is unlikely to be filled by donors and philanthropists alone. Who will step up and pay for new TB treatments? 


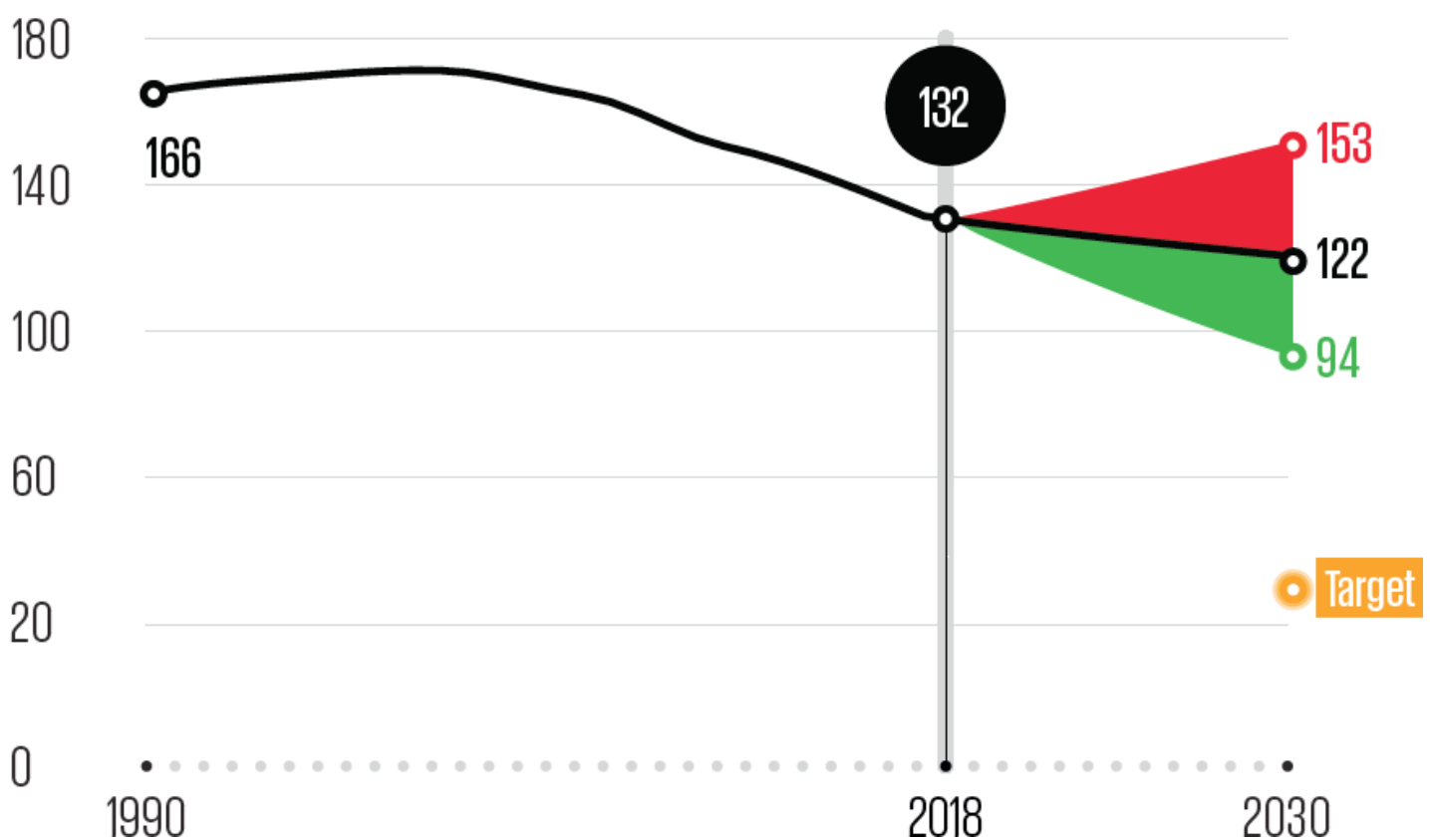

Figure 1 New cases of tuberculosis per 100000 people. Source IHME. BRICS, Brazil, Russia, India,China and South Africa; HTA, health technology assessment; LMICs, low- and middle-income countries; MICs, middle-income countries. ${ }^{24}$

\section{EMERGING ECONOMIES: EPICENTRE OF THE TB EPIDEMIC, SOURCE OF A TRANSFORMATIONAL SOLUTION?}

Most TB patients live in fast-growing, emerging economies. Many of these countries have already lost eligibility for traditional donor aid or are currently mid-transition and just five middle-income countries (MICs)-India, China, Indonesia, Russia and South Africa-account for over 40 per cent of TB cases and 55 per cent of cases with multi-drug resistance. They will get the greatest benefit from new TB treatments. Could the most-affected countries also take the lead in shaping an innovation agenda?

There are some positive political signals. The 2018 United Nations high-level meeting on $\mathrm{TB}^{6}$ indicated global momentum to step up the fight. TB featured prominently ${ }^{7}$ in discussions and communiqués ${ }^{8}$ at the annual Brazil, Russia, India,China and South Africa (BRICS) summits; ${ }^{910}$ the BRICS also launched a joint TB Research Network ${ }^{11}$ in 2016. Indian Prime Minister Modi recently announced a plan to end TB in India by $2025,{ }^{12}$ and India has added $\$ 740$ million to its national TB programme, roughly quintupling its investment. ${ }^{13}$ The Chinese First Lady is a TB global champion ${ }^{14}$ and, in 2017, Russian President Putin ${ }^{15}$ opened the WHO Global Ministerial Conference on Ending TB, ${ }^{16}$ publicly committing Russia to the global fight.

However, in spite of these political commitments, the fragmentation of the global TB market across multiple less lucrative markets, combined with scientific risk, deters sustained private sector investment in R\&D.
Because these high burden countries lack an effective mechanism to 'pool' their burden and resources-and thus signal the existence of an attractive, commercial market-there remains no cost-effective way for any individual country to address its disease burden through medical innovation.

\section{OUR PROPOSAL: THE MARKET-DRIVEN,VALUE-BASED ADVANCE COMMITMENT}

With the right mechanism, we can leverage today's political commitment to transform the landscape of TB innovation-from a struggling, donor-dependent ecosystem to a vibrant, country-driven marketplace delivering new treatments at affordable prices. We propose a new innovation model-the market-driven,value-based advance commitment (MVAC) $)^{17}$ - that creates and guarantees a market for new TB drugs if and when innovators launch a breakthrough TB regimen. We define the latter as a short, universal regimen which tackles different types of $\mathrm{TB}$, including drug-resistant strains.

The MVAC draws on Gavi's Advanced Market Commitment (AMC) ${ }^{18}$ for pneumococcal vaccine. ${ }^{19}$ Like the AMC, the MVAC includes an advance commitment to purchase a product, if it materialises, at a pre-agreed price-volume combination (which results in the agreed market value.) Key differentiating factors, outlined in table 1, include these: 
Table 1 Leveraging the lessons learnt from previous AMCs to new models

\begin{tabular}{ll}
\hline Key factor & AMC pilot for pneumococcal vaccines \\
\hline $\begin{array}{l}\text { Time frame for } \\
\text { meeting the TPP }\end{array}$ & $\begin{array}{l}\text { Short, as products were in late stage of } \\
\text { development }\end{array}$ \\
TPP & $\begin{array}{l}\text { Product specifications defined by WHO experts } \\
\text { including minimal characteristics to get reward }\end{array}$ \\
\hline
\end{tabular}

\section{MVAC for TB}

Long, as potential candidates are in pre-clinical/early stage of development

Product specifications defined by country payers, drawing on expert advice. Expert group to decide (as part of the governance) the minimum characteristics to get some reward. There are proposals around the minimum TPP, but these need to be reviewed and endorsed by the technical committee and ultimately by the countries.

Initial AMC price (paid by donors to recover
manufacturing investment) of $\$ 7$, subsequently
reduced to a tail price of $\$ 3.50$, set at an estimate of
the marginal cost of production. The $\$ 3.50$ became
the minimum price.
Competition
generation and second-generation products
Initial contract not to take all of the
commitment
Companies could compete on price and
quality
Effectively, however, rewarded two companies

$\begin{array}{lll}\begin{array}{l}\text { Countries it is } \\ \text { designed for }\end{array} & \text { Designed to engage donor countries } & \text { particular countries transitioning away from aid; TB } \\ & & \text { burden concentrated in large MICs and low-income } \\ & \text { countries }\end{array}$

Governance

- WHO experts defined the TPP

- Gavi served as secretariat and supported eligible countries to purchase the product

- The World Bank guaranteed the AMC fund

- UNICEF managed the supply agreements
Price based on health technology assessment (HTA) value assessment of the TPP and on local ability to pay of BRICS. Different prices in different countries. Prices adjusted to reflect percentage of TPP met in practice by the products.

- Non-exclusive scheme to cover first-generation and second-generation products

- Companies can in principle compete on price and quality; however, complexity of meeting TPP means combinations are likely and competition unlikely.

- Global secretariat (to be determined) and decision-making function on key scheme elements

- Advisory/expert committee (with MICs, global TB and HTA experts, donors, other stakeholders) to provide recommendations on the extent to which the new product meets the TPP

$\begin{aligned} & \text { Role of companies } \\ & \text { (developers and/or } \\ & \text { manufacturers) }\end{aligned}$
$\begin{gathered}\text { Enter the AMC Registered Manufacturers } \\ \text { Agreement } \\ \text { Scale up manufacturing capacity to meet } \\ \text { Gavi-eligible countries' demand for } 10 \text { years }\end{gathered}$
Who bears the risk? $\quad \begin{gathered}\text { Manufacturer bore R\&D and manufacturing } \\ \text { risk, donor bore volume risk }\end{gathered}$

- Register interest at an early stage

- Develop and submit regulatory and HTA dossiers for the new product

- Commit to developing manufacturing capacity for the agreed period of time and price

- Show willingness to engage in a commercial agreement involving post-launch evidence collection

- Multilateral development banks (MDBs) underwrite, companies bear R\&D risk, countries bear volume risk (ie, commit to buying a certain value of the product)

AMC definition and governance (WHO, Gavi,
UNICEF)
Price top-up to reward innovation (global
donors)

Role of LMICs $\quad$ Originally expected to contribute with a copay as a share of the tail price but in practice this has been met by global donors

- Facilitate scheme establishment

- Help mobilise political support for the proposal

- Potentially help cover costs for MVAC secretariat; subsidise or cover commitment fees for MDB guarantees; provide research grant funding for BRICS research bodies

- Actively involved in the definition of the scheme

- Committing to pay a predefined price for a predefined volume based on their budget constraints and value offered by the prospective intervention(s)

\begin{tabular}{lll}
$\begin{array}{l}\text { Role of financing } \\
\text { intermediaries }\end{array}$ & $\begin{array}{l}\text { Donors guaranteed funding to Gavi. No } \\
\text { intermediary. }\end{array}$ & $\begin{array}{l}\text { Potential role for an MDB to provide loan financing } \\
\text { to assist in guaranteeing the recipient commitments }\end{array}$ \\
\hline
\end{tabular}

AMC, Advanced Market Commitment; BRICS, Brazil, Russia, India, China and South Africa; HICs, high-income countries; LMICs, low- and middle-income countries; MICs, middle-income countries; MVAC, market-driven, value-based advance commitment; R\&D, research and development; TB, tuberculosis; TPP, target product profile. 
Health Technology Assessment:

To estimate the size of the market including potential price and volumes for the TB universal regimen target product profile (TPP) which will be translated into commitments and implementation/success payments

\section{Governance:}

To develop a governance model which coordinates BRICS and donors, establishing credibility.
Guaranteeing the Commitment:

To calculate and guarantee an advance purchase commitment from MICs for a new TB regimen to address MIC- or TB-specific risks.

\section{Industrial Policy:}

To ensure alignment with industrial policy objectives of MICs, including local TB manufacturing capacity and requirements.

Figure 2 Market-driven,value-based advance commitment. SDG,Sustainable Development Goal; TB, tuberculosis.

1. Use of healthtechnology assessment (HTA) ensures prices are affordable and reflect value for payers;

2. Countries are not required to either pool or set aside funds until the regimen receives marketing authorisation; in the interim, they can use their healthcare budgets to buy products and services rather than fund R\&D directly. Countries only pay for products they buy and receive.

3. Most importantly, the initiative is country-driven (vs donor-driven). Countries affected by TB would make advanced purchase commitments based on the local value of a universal TB regimen. These commitments are subsequently guaranteed by a multilateral development bank (MDB) intermediary, with ultimate accountability (to the MDB) based on countries sovereign credit-worthiness.

4. The poorest (low-income) countries would not be part of the MVAC; however, the contractual arrangement with the innovator would ensure they receive cost-plus access. The innovator could opt to licence the product to a generics manufacturer, potentially facilitated by the Medicines Patent Pool. ${ }^{20}$

Below we describe the MVAC's four core elements as illustrated in figure 2.

\section{Element 1: HTA to support coverage decisions from the payer's perspective}

In 2014, the World Health Assembly endorsed HTA to help countries prioritise healthcare spending for universal health coverage. Low- and middle-income countries (LMICs) increasingly draw on HTA evidence when deciding whether new products should be adopted and/or eligible for public subsidy or reimbursement. HTA has also been applied by product developers early in the development process to assess pricing options and inform investment decisions.

For the MVAC, we propose to merge these two applications of HTA. We used well-validated TB epidemiology and health economic models ${ }^{21}$ to predict the likely value of a TB regimen in a sample of high-burden countries; this value assessment serves as the starting point for a price and volume commitment. Our HTA model is based on local country affordability thresholds, calibrated against future budgets; we also imagine a scenario where many new TB technologies (eg, TB vaccines, short regimens, new diagnostic tests) and policies (eg, aggressive private sector engagement in $\mathrm{TB}$ treatment in India) will be introduced, inflecting the comparator standard of care and therefore the value of the breakthrough regimen

We define the TB breakthrough innovation based on a single cross-country target product profile (TPP), previously developed through a WHO collaborative process, to tackle both drug resistance and the need for a shorter regimen. However, even a breakthrough regimen may not meet the entire TPP wish list, hence health gains need to be assessed on a country-by-country basis. Countries would need, however, to collectively define a minimum acceptable TPP to trigger the MVAC commitment; above the minimum threshold, more effective products would create additional value, and therefore generate a higher price and volume commitment.

\section{Element 2: guaranteeing the commitment}

MIC purchase commitments can only prompt industry investment if they are perceived as highly credible. A commitment guarantee-underwritten by a financial intermediary-would help ensure that MICs credibly signal their demand and willingness to pay. The size of the commitment guarantees could vary depending on how many MICs were willing to participate.

To guarantee countries' purchase commitments, countries would leverage their own sovereign creditworthiness-intermediated through a AAA-rated intermediary guarantor such as a MDB-to underwrite the advance commitments. After the drug comes to market, the country would have (say) 10 years to fulfil the entirety of its purchase commitment by purchasing drugs directly from the originator company or a local authorised licensee. If a commitment balance remains at the end of the 10-year window-that is, if a country were to partially or fully renege on its purchase commitment-the remaining balance would convert to a loan by the MDB, subject to repayment by the commitment-making country under pre-agreed terms. The remaining drug purchase commitment would be honoured by the MDB on behalf of the country, and the drugs would be supplied for the country 
to use as it thought appropriate. Note that no funds need be set aside by national payers prior to the launch of the product; at launch, countries would purchase the eligible product through standard budgetary, procurement and contractual mechanisms at a cost-effective and locally affordable price.

\section{Element 3: governance with national governments and local civil society in the driving seat}

The MVAC is a vehicle for multinational and multistakeholder cooperation; ultimately, its structure and operations must be owned and governed by participating countries' governments and civil society, in partnership with trusted global experts, institutional stakeholders and local and multinational industry. A Board of participating country governments, advised and informed by an HTA Technical Advisory Committee comprised of civil society, experts, patient advocates and other stakeholders, would hold ultimate decision-making authority. In turn, the Board would delegate day-to-day operations-for example, commissioning HTA models and analyses, preparing contracts and facilitating negotiations-to a permanent secretariat. This body would work hand-inhand with existing or budding HTA/priority-setting institutions in participating countries.

Based on a needs' assessment and broad consultation, we identified a World Bank trust fund as the best fit to host an MVAC secretariat. The World Bank is a credible multilateral institution-both for potential industry partners and for MICs, which already participate in institutional governance and could oversee a dedicated trust fund. The trust fund model is widely used to steward development resources and is well-trusted by the donors who might subsidise the secretariat's operational costs. It can provide predictable multi-year funding-potentially using a single up-front investment to finance the MVAC secretariat over the entirety of its long-term life cycle.

\section{Element 4: industrial policy}

Most BRICS countries have industrial strategies to support domestic companies, including within the pharmaceutical sector; these can include requirements for localisation, local manufacturing and/or clinical development partnerships. A successful MVAC innovator company could be expected to meet countries' industrial policy requirements by, for example, licensing production to local manufacturers. Given high overall expected volumes, technology transfer models and license agreements between multinational developers and local manufacturing companies could help secure long-term supply; in so doing, it would be essential to ensure high quality and avoid unnecessary duplication.

Our approach respects both affordability considerations and intellectual property (IP) by moving price negotiations further upstream. Rather than waiting for a lifesaving product to (hopefully) come to market and then attempting to secure an affordable price-which may include either the threat of or application of compulsory
licensing-MVAC country governments and industry will agree to a locally affordable but still profitable price before the drug is developed, simultaneously ensuring that industry will make the requisite investments to bring the product to market and that the product will be accessible to all who need it once launched. As a result, participating countries will not need to use Trade-Related Aspects of Intellectual Property Rights (TRIPS) flexibilities for this particular product and will agree to respect the originator IP rights, so long as the IP-holder offers the product at the pre-agreed affordable price. Ability to use TRIPS flexibilities remain in place for non-participating countries, and for all products not covered by an explicit MVAC agreement. To ensure that critical breakthrough treatments are not lost in the event that a developer should fail to follow through on the terms of MVAC, the agreement may include step-in-rights, allowing participating governments and the Secretariat to make the product available to MICs and LICs, respectively, as per the terms of the agreement.

\section{A WORK IN PROGRESS}

We have developed this proposal in close consultation with a broad range of stakeholders including civil society, international bodies, industry and national governments. We shared a draft of our thinking publicly in March $2019,{ }^{22}$ sparking further discussion and collaborative problem-solving, and we continue to welcome constructive dialogue and engagement.

We do not have all the answers. Some key unresolved questions include: How will this model interface with other arrangements, such as the Life Prize? Can we encourage investment from small and medium enterprises-not just large multinational corporations? Will national payers agree to a differential pricing approach, potentially paying more than other countries if they reap higher value? Can we agree to put aside (for now) differences of opinion about intellectual property and de-linkage if we can ensure we achieve the key shared goal: access to lifesaving innovation at affordable prices? ? $^{23}$

\section{WE CANNOT AFFORD INACTION}

Beyond addressing the immediate challenge of $\mathrm{TB}$, our proposal $^{17}$ offers a roadmap to leverage private-sector investment for LMIC health priorities. Through the MVAC, countries can strengthen their own technical HTA capacity to shape pharmaceutical policy and help secure affordable prices, as national health schemes in the UK, Australian and elsewhere have been doing for years. A value-based advance market commitment, supported by a multilateral development bank guarantee, can build trust between the demand and supply sides; this 'bridging' mechanism can help transition to a more functional relationship between industry and country governments that incentivises private-sector R\&D investment into the diseases of the poor and vulnerable. 
With 1.6 million people dying from TB each year, and few private sector resources going toward LMIC country disease priorities, we desperately need a new approach to health R\&D and with an estimated $\$ 2.5$ trillion financing gap to achieve the SustainableDevelopment Goals, business as usual means we will fail to achieve global health and development targets. We call on the global community and MIC leaders to take bold action and support and secure MVAC as a tool we need for the journey to build a TB-free world.

Acknowledgements The authors are solely responsible for the content of this article, including all errors or omissions; acknowledgements do not imply endorsement of the content. We are grateful for editorial support from Lydia Regan, Center for Global Development, and for technical advice and input from Brenda Waning, Associate Professor of Pharmacology and Toxicology, Massachusetts College of Pharmacy and Allied Health Sciences; Frank Cobelens, Professor of Epidemiology and Control of Poverty-Related Infectious Diseases, University of Amsterdam; Richard Wilder, Associate General Counsel in the Global Health Program at the Bill \& Melinda Gates Foundation; Carlos Gadelha, Secretary of Science, Technology and Strategic Products at the Brazilian Ministry of Health and Robert Newman, Director of AMP Health.

Funding This study was funded by Bill \& Melinda Gates Foundation (Grant: OPP1191987).

\section{Patient consent for publication Not required.}

Provenance and peer review Not commissioned; externally peer reviewed.

Data availability statement There are no data in this work.

Open access This is an open access article distributed in accordance with the Creative Commons Attribution 4.0 Unported (CC BY 4.0) license, which permits others to copy, redistribute, remix, transform and build upon this work for any purpose, provided the original work is properly cited, a link to the licence is given, and indication of whether changes were made. See: https://creativecommons.org/ licenses/by/4.0/.

Author note Modelling work completed by Anna Vassall, Gabriela Gomez, Nim Pathy and Lotte Steuten. The full results will be published in 2020. For details of analytics or methods, contact Anna Vassall (Anna.Vassall@Ishtm.ac.uk) or Gabriela Gomez Gabriela (Gomez@Ishtm.ac.uk).

\section{REFERENCES}

1 World Health Organization. Tuberculosis Key Facts [Webpage], 2018. Available: https://www.who.int/news-room/fact-sheets/detail/ tuberculosis [Accessed September 2019].

2 World Health Organization. Global Tuberculosis Report 2018 [Online]. Geneva: World Health Organization; 21 September 2018. Available: https://www.who.int/tb/publications/global_report/en/ [Accessed September 2019].

3 G-FINDER. Neglected Disease Research \& Development: Reaching new heights. Geneva. Policy Cures Research. [Report] 2018.

4 Treatment Action Group. Tuberculosis research funding trends 20052018, 2019. Available: https://www.treatmentactiongroup.org/wpcontent/uploads/2019/12/tbrd_2019_web.pdf [Accessed January 2020].

5 Clift C. Review of progress on antimicrobial resistance: background and analysis. centre on global health security, Chatham house, 2019. Available: https://www.chathamhouse.org/sites/default/files/ publications/research/2019-10-11-AMR-Full-Paper.pdf [Accessed January 2020].

6 World Health Organization. Un General assembly high-level meeting on ending TB, New York, 26 September 2018. Available: https:// www.who.int/tb/features_archive/UNGA_HLM_ending_TB/en/ [Accessed September 2019].

7 Silverman R, Chalkidou K, Towse A. As UN General Assembly Highlights Tuberculosis Fight, Will BRICS Lead on the R\&D Agenda?: Center for Global Development, 2018. Available: https://www.cgdev. org/blog/un-general-assembly-highlights-tuberculosis-fight-willbrics-lead-rd-agenda [Accessed September 2019].
8 Draft Joint Communiqué of the 8th BRICS Health Ministers Meeting 20th July 2018, Durban, South Africa [Conference Communication]. BRICS, 20 July 2018. Available: https://static-0.rosminzdrav.ru/ system/attachments/attaches/000/039/220/original/ИТОГОВОЕ_ коммюнике_8-й_встречи_Б ИКС.pdf?1532166706 [Accessed September 2019].

9 9th BRICS Summit. BRICS leaders Xiamen declaration. Xiamen, China, September 4, 2017. Available: http://www.itamaraty.gov.br/ en/press-releases/17427-9th-brics-summit-brics-leaders-xiamendeclaration-xiamen-china-september-4-2017 [Accessed September 2019].

10 10th BRICS Summit. Johannesburg Declaration. Johannesburg, South Africa, 25 - 27 July 2018. Available: https://www.mea.gov. in/bilateral-documents.htm?dt//30190/10th_BRICS_Summit_ Johannesburg Declaration [Accessed September 2019].

11 Board G. BRICS TB research network to accelerate research and innovation through collaboration across the BRICS countries: TB online, 2018. Available: http://www.tbonline.info/posts/2018/7/1/ brics-tb-research-network-accelerate-research-and-/ [Accessed September 2019].

12 Pm Narendra Modi launches campaign to eradicate TB from India by 2025: the times of India. 2018 [updated $2018 \mathrm{https}: / /$ timesofindia. indiatimes.com/india/pm-narendra-modi-launches-campaignto-eradicate-tb-from-india-by-2025/articleshow/63282222.cms (accessed September 2019).

13 Strong role for private sector in Global Fund's TB grants to India: Aidspan; 2018 [updated February 2018]. Available: http://www. aidspan.org/gfo_article/strong-role-private-sector-global-funds-tbgrants-india [Accessed September 2019].

14 Chinese first lady calls for global efforts against TB: China daily. 2018 [updated 2018 http://www.chinadaily.com.cn/a/201809/27/ WS5babebc5a310c4cc775e8413.html (accessed September 2019).

15 Putin, Ally AU. Supports the global effort to stop tuberculosis: Huffpost. 2017 [updated 2017 https://consent.yahoo.com/ collectConsent?sessionld=3_cc-session_41436d57-3db1-4c3aae5d-cc5420aa863a\&lang=en-gb\&inline $=$ false (accessed September 2019).

16 Global Ministerial conference on ending TB in the sustainable development era, 16-17 November 2017: Moscow. Available: https://www.who.int/mediacentre/events/2017/ministerialconference-tb/en/ [Accessed September 2019].

17 Chalkidou K, Garau M, Silverman, R M, et al. 2020 blueprint for a Market-Driven value-based advance commitment (MVAC) for tuberculosis. center for global development and the office of health economics. Available: https://www.cgdev.org/publication/blueprintmarket-driven-value-based-advance-commitment-tuberculosis [Accessed January 2020].

18 Levine R, Kremer M, Albright A. The report of the center for global development advance market commitment Working Group. center for global development, 2005. Available: https://www.cgdev.org/ sites/default/files/archive/doc/books/vaccine/MakingMarketscomplete.pdf [Accessed January 2020].

19 The AMC Secretariat of GAVI, The Vaccine Alliance. Advance market commitment for pneumococcal vaccines annual report 1 January - 31 December 2018, 2019. Available: https://www.gavi.org/sites/ default/files/document/2018-pneumococcal-amc-annual-reportpdf. pdf [Accessed January 2020].

20 Medicines Patent Pool. Expanding access to public health. Available: https://medicinespatentpool.org/uploads/2019/07/ Brochure_EN.pdf [Accessed January 2020].

21 Gomez GB, Dowdy DW, Bastos ML, et al. Cost and costeffectiveness of tuberculosis treatment shortening: a model-based analysis. BMC Infect Dis 2016;16:726.

22 Chalkidou K, Garau M, Nemzoff C, et al. 2019 blueprint for a MarketDriven value-based advance commitment (MVAC) for tuberculosis. center for global development and the office of health economics. Available: https://www.cgdev.org/sites/default/files/MVAC-Blueprintfor-Consultation-2019-02-28.pdf?callout=1-1 [Accessed January 2020].

23 Silverman R, Chalkidou K, Towse A. We Asked, You Answered: Reflections On The First Round Of MVAC Feedback". Center for Global Development, 2019. Available: https://www.cgdev.org/blog/ we-asked-you-answered-reflections-first-round-mvac-feedback [Accessed January 2020].

24 Bill \& Melinda Gates Foundation. Goalkeepers: examining inequality, 2019. Available: https://www.gatesfoundation.org/goalkeepers/ report/2019-report/?download=true [Accessed 6 April 2020]. 